\title{
Contribution of larval growth rate variability to the recruitment of the Bay of Málaga anchovy (SW Mediterranean) during the 2000-2001 spawning seasons*
}

\author{
ALBERTO GARCÍA, DOLORES CORTÉS, TEODORO RAMÍREZ, ANA GIRÁLDEZ \\ and ÁNGEL CARPENA
}

Instituto Español de Oceanografía, Centro Oceanográfico de Málaga, Aptdo. 285, 29640 Fuengirola, Málaga, España. E-mail: agarcia@ma.ieo.es

\begin{abstract}
SUMMARY: Daily growth rates were estimated from larval anchovy (Engraulis encrasicolus) sampled in their main nursery grounds off the Bay of Málaga (SW Mediterranean) during the 2000 and 2001 spawning seasons. Significantly higher growth rates were observed in the 2001 larval population, representing a $20 \%$ increase through the larval size classes analysed. The decimated SW Mediterranean anchovy population experienced a successful anchovy recruitment during this year estimated at 13,000 tons for the Bay of Málaga by the acoustic evaluation of small pelagic resources. The size distribution of the recruited anchovy juveniles during 2000 and 2001 showed an increase of approximately $2 \mathrm{~cm}$. Their corresponding anchovy spawning seasonality agrees with the estimates from the growth model fits of each year. Data on the environmental background for the two years sampled are provided by a historical quarterly monitoring project. Zooplankton showed a two-fold significant increase during July 2001, coastwise as well as offshore. No significant changes in surface temperature were observed between years. Instead of the usual summer spawning peak, anchovy peak spawning shifted towards early spring during the 2001 spawning season. The study provides evidence from field data on the relationships of larval growth variability and recruitment.
\end{abstract}

Key words: anchovy, larvae, Mediterranean, growth, nursery ground, environment, recruitment.

RESUMEN: CONTRIBUCIÓN DEL CRECIMIENTO LARVARIO AL RECLUTAMIENTO DEL BOQUERÓN DE LA BAHÍA DE MÁLAGA EN LOS AÑOS 2000-2001. - Las tasas de crecimiento diario de larvas de anchoa (Engraulis encrasicolus) fueron estimadas de una población larvaria procedente de la principal zona de alevinaje de la Bahía de Málaga (Mediterráneo Sur-occidental) durante la época de puesta de los años 2000 y 2001. Las tasas de crecimiento diario de la población del 2001 fueron significativamente mas altas, representando un aumento del $20 \%$ en todas las clases de tallas larvarias analizadas. Durante el año 2001, se produjo un importante aumento del reclutamiento de anchoa estimado por el método acústico en 13,000 TM en la Bahía de Málaga. La distribución de tallas de los reclutas de anchoa presentó un aumento de $2 \mathrm{~cm}$ aproximadamente entre los años 2000 y 2001. La estacionalidad de la puesta se corresponde con las estimaciones del modelo de crecimiento para cada año. Los datos del medio-ambiente para los 2 años muestreados son aportados por un proyecto de seguimiento trimestral de las condiciones oceanográficas. La biomasa zooplanctónica aumentó de forma significativa, en costa como en mar abierto, durante Julio del 2001. Sin embargo, no se observaron cambios significativos en la temperatura superficial entre años. En el 2001, se observa un adelanto a primavera de la puesta de la anchoa. Este estudio evidencia a partir de datos de campo la relación entre variabilidad del crecimiento larvario y reclutamiento.

Palabras clave: anchoa, larvas, Mediterráneo, crecimiento, zonas de alevinaje, medio-ambiente, reclutamiento.

*Received February 12, 2003. Accepted June 30, 2003. 


\section{INTRODUCTION}

The Alborán Sea anchovy (Engraulis encrasicolus) is the most economically valued of the small pelagic species. Unfortunately, its resources suffered a drastic decline during the mid-eighties (Giráldez and Abad, 2000). At its peak, landings amounted to 28,000 tons during 1982, among which $87 \%$ corresponded to catches from the Southern Alborán and 13\% to catches from the Northern Alborán (Giráldez and Abad, 1991). The lowest landings occurred during 1993, coinciding with a poor recruitment that may have been caused by the bloom of a species of mesopelagic nature, Capros aper, in the Alborán Sea (Abad and Giráldez, 1990). Though fishing effort applied by the purse-seine fishery has decreased during the last two decades from 203 vessels in 1980 to 120 in 2001 (Giráldez and Alemany, 2002a), the anchovy resources have not recovered to the biomass levels prior to their decline. Since then, the main bulk of the anchovy resource from the northern coasts of the Alborán Sea has been concentrated in the Bay of Málaga, whose port lands on average as much as $85 \%$ of the total catch from the southern Mediterranean region. Therefore, the landings from this port represent a proxy of the stock's abundance, and since the fishery principally captures -0 age classes, it also represents the recruitment trend (Giráldez and Alemany, 2002a).

The nursery grounds of the species are concentrated near the coasts facing the city of Málaga, where in the past inshore artisanal fisheries based on beach seine fishing gear exploited its larval stages intensively as described by García et al., 1981 and Reina-Hervás and Serrano, 1987.

Based on the observation of their reproductive parameters, Giráldez and Abad (1995) set their spawning season from early spring to early autumn, with a peak in June-July. With regard to ichthyoplanktonic abundance, Rodriguez (1990) and Rodriguez and Rubín (1986) find anchovy eggs from May to November, while maximums were observed in August when surface temperatures ranged from $19-23{ }^{\circ} \mathrm{C}$.

Within the framework of a national funded project on the "Effect of abiotic and biotic factors on the distribution, abundance, viability of eggs and larvae of exploited fish populations" (CICYT MAR19990328-CO--03), larval anchovies were sampled in the nursery grounds off the Bay of Malaga during the 2000 and 2001 anchovy spawning seasons to assess the influence of environmental conditions on their daily growth.
The ECOMALAGA quarterly monitoring programme of the Instituto Español de Oceanografía provided the data on the environmental and oceanographic variables of the Bay of Málaga and its surrounding waters. To assess the impact of differential growth rates observed between the two years on the recruited population, data from the ECOMED project on the acoustic evaluation of small pelagic resources during the anchovy recruitment season were also provided.

It is generally recognised that recruitment success in most pelagic fish is determined by the degree of survival in their early life stages. Mortality in these stages can be caused by numerous reasons, such as predation, starvation and hydrological transport to unfavourable feeding grounds, yet the way that these factors interact is still a matter of debate among researchers (Bailey and Houde, 1989; Legget and DeBlois, 1994). A poor growth rate may lead to an increase in mortality due to the prolongation of time spans within vulnerable larval sizes (Folkvord and Hunter, 1986). Predation was shown to have a much higher impact on mortality than starvation in the Bay anchovy (Anchoa mitchilli) (Leak and Houde, 1987). Houde (1987) from literature derived data indicated that small variations in the growth rates could lead to major recruitment variations.

The analysis of otolith microstructure offers great potential for analysing the daily growth of the larval stages, which in small pelagic species are most susceptible to mortality (Houde, 1987). The daily deposition of increments on otoliths allows age determination and growth analysis (Geffen, 1982, Campana and Nielson, 1985) in a number of species. From the environmental viewpoint, otolith microstructure also provides a tool, for assessing the seasonal, environmental or geographic differences observed through the analysis of increment widths and growth rate differences (Campana and Neilson 1982; Moksness and Fossum 1991; García et al., 1998).

With increasing larval age, certain advantages are observed in the analysis of otolith microstructure. Daily increments are sharper and more distinct with age, thus facilitating a greater precision of age estimates. An otolith intercalibration exercise among experienced readers showed a coefficient of variation in the readings of less than 10 day old larvae of $30 \%$, decreasing to $10 \%$ over this age (Moksness et al., 2000). Another advantage lies in the longer historical record of an individual larva registered in the otolith. The transition from the early 


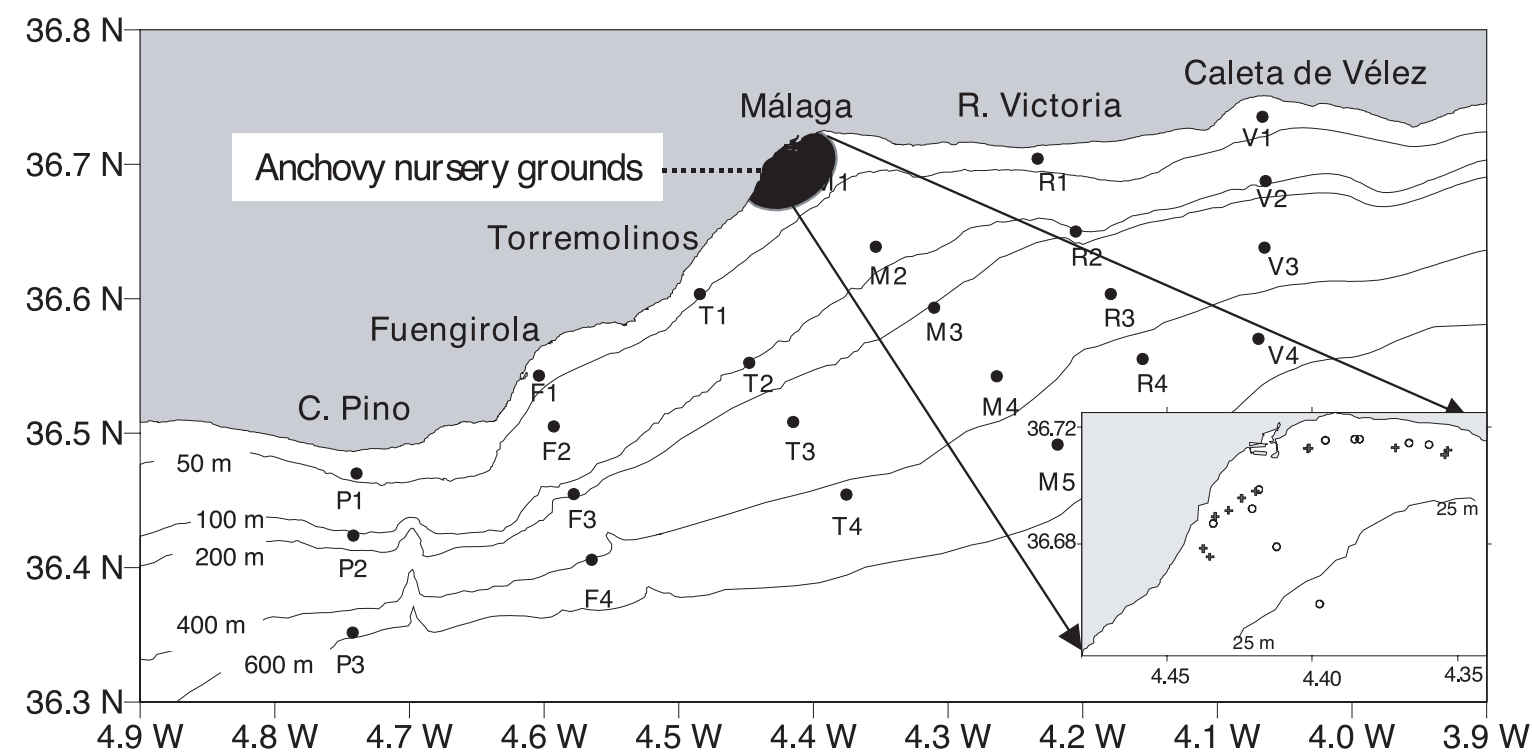

FIG. 1. - Study area of the ECOMALAGA monitoring program. Points denote CTD and Bongo $40 \mathrm{~cm}$ stations. The lower amplified map indicates the site of $1 \mathrm{~m}$ Bongo hauls (indicated as + for July 2000 and $\mathrm{O}$ for July 2001) carried out specifically for the anchovy daily growth study.

ontogenic stages to later developmental stages (e.g. endogenous to exogenous feeding, the initial growth bursts) and environmental changes leave check marks in the otoliths of larvae. Mortality in anchovy larvae declines with age during the developmental stages and their survival is growth-rate dependent (Rilling and Houde, 1999). Therefore, it is believed that an approximation to the pre-recruitment stage can yield a better growth to recruitment relationship (Peterman et al., 1988). The nursery grounds off the coasts of Malaga, once renowned for their intensive fishing capacity for anchovy/sardine fry, provide an excellent site for verifying growth characteristics and survivorship to recruitment.

\section{MATERIALS AND METHODS}

The environmental characteristics of this study on daily larval growth of anchovy is provided by the ECOMALAGA monitoring programme (Camiñas et al., 1996), based on the information acquired from 24 oceanographic stations distributed in 6 transects perpendicular to the coastline (Fig. 1) with a quarterly sampling frequency.

\section{Sampling at sea}

The seawater properties of the water column were monitored by means of a Seabird 25 CTD profiler to $300 \mathrm{~m}$ depth where possible at each of the 24 stations. Niskin water bottle samples were taken at different depth strata (surface, 10, 20, 50 and $100 \mathrm{~m}$ ) to estimate chlorophyll $a$ content by filtering 2 litres through a Whatman $\mathrm{GF} / \mathrm{F}$ filter $(0.7 \mu \mathrm{m})$. Filters were conserved at $-20^{\circ} \mathrm{C}$ in plastic tubes with silicagel.

The abundance of anchovy eggs and larvae was delimitated in the area by means of Bongo $(40 \mathrm{~cm}$ $\varnothing)$ oblique tows to $100 \mathrm{~m}$ depth where possible, using nets of $200 \mu \mathrm{m}$ mesh size geared with General Oceanics 2030 flowmeters. The plankton hauls were carried out at a ship speed of 2 knots, while the largest size classes of anchovy larvae used for the daily growth study were exclusively sampled in their nursery grounds off the coasts of Málaga city during July 2000 and 2001. They were sampled by a Bongo gear of cuadrangular aperture measuring $1 \mathrm{~m}$ diagonally equipped with a black tinted net of $1 \mathrm{~mm}$ mesh size to reduce avoidance of late larval stages. Moreover, all tows were carried out at night when anchovy larvae school at surface layers, inflating their gas bladders. The tows were superficial and over average depths of 10-15 m. Tow duration was fixed to 10 minutes to prevent damage to larva at a speed of 2 knots. Upon retrieval of the net, the codends were washed gently in buckets filled with water so as to facilitate the sorting of larvae on board by placing the washed samples on glass trays. The sorted larvae were placed in cryogenic vials and conserved immediately in liquid nitrogen. The situation of the tows was random in the nursery area in search 
of larval schools. Whenever a significant number of individuals had been fished, a tow was repeated in the same area to increase sample size.

\section{Laboratory analysis}

One of the samples of the Bongo 40 tow was used to estimate mesozooplankton biomass, while the other was used to sort the fish eggs and larvae in order to map their distribution. The sample for mesozooplankton biomass estimation was frozen on board, defrosted and weighed in the laboratory, and later dried for 24 hours at $60^{\circ} \mathrm{C}$ for weighing with a precision balance.

The major and minor axis and perimeter of the sorted anchovy eggs were measured by means of an image analysis system.

Chlorophyll $a$ was extracted with acetone $90 \%$ for $24 \mathrm{~h}$ at $4^{\circ} \mathrm{C}$ in the dark, and subsequently analysed by spectrophotometry (SCOR-UNESCO 1966).

Anchovy larvae sampled in the nursery grounds with the $1 \mathrm{~m}$ Bongo gear were transferred from the liquid nitrogen containers to $\mathrm{a}-80^{\circ} \mathrm{C}$ freezer until the moment of otolith extraction. Before extracting otoliths, larvae that were randomly selected from the vials were thawed at ambient temperature. The defrosted larvae were standard length measured by projecting them on a computer monitor using the image analysis program Image of NIH (National Health Institute of USA). After measuring, the larvae were dehydrated in the dry freezer CHRIST Alpha 2-4 for 24 hours. Larvae were then dry weighed on the precision balance Sartorius M2P 1 $\mu \mathrm{g}$. After dry weighing, larvae were re-hydrated with distilled water to facilitate otolith extraction. The otoliths were extracted by fine needles and dropped onto the slide. They were then cleansed with a drop of distilled water. Once dried, the sagittae were fixed to the slide with nail lacquer.

The age interpretation was done with the sagittae using the OTO program designed by Andersen and Moksness (1988). To run this program, the following equipment is needed: a video monitor, a high resolution camera inserted in the microscope and a HEI digitiser connected to a Macintosh computer system. The count of increments and the measurement of widths of increments and nucleus are all done under 1000X magnitude. The criteria for interpreting the increments were established by means of an otolith intercalibration workshop held among experienced age readers (Anonymous, 1993).
Standard length-at-age data were fitted using a power model $\left(\mathrm{SL}=\mathrm{SL}_{0}+\alpha \cdot \mathrm{Age}^{\beta}\right)$. In this model the intercept was fixed at $2.7 \mathrm{~mm}$ in order to minimise any possible bias due to growth rate effects (Campana and Jones, 1992). This value corresponds to the standard length at hatching for the Adriatic anchovy Dulčic (1997). Likewise, otolith radius vs age was fitted using a power model $\left(\mathrm{R}=\mathrm{R}_{0}+\delta \cdot \mathrm{Age}^{\phi}\right)$ in which the radius at hatching date $R_{0}$ was fixed at 4.3 and $4.7 \mu \mathrm{m}$, the average values at hatch observed for the sampled larval anchovy populations. For the estimation of individual somatic growth rates $(\mathrm{mm} /$ day) we used the following equation:

$$
\left(\mathrm{L}_{2}-\mathrm{L}_{0}\right) / \mathrm{t} \text {, }
$$

where $\mathrm{L}_{0}$ represents the mean size at hatch of the population $(2.7 \mathrm{~mm})$. In a similar manner, the individual growth rate of otoliths were estimated.

The expected growth rate at a given age was calculated through the derivative of size (SL, otolith radius) at age functions. The daily growth rate in length $\left(\mathrm{mm} \_\mathrm{d}^{-1}\right)$ at age $=\mathrm{t}$ was estimated according to the formula:

$$
\mathrm{dSL} / \mathrm{dt}=\alpha \cdot \beta \cdot \mathrm{t}^{(\beta-1)}
$$

One factor ANOVA were applied to test differences between years (e.g. zooplankton biomass, anchovy egg sizes). ANCOVA on log transformed data was used to test differences in the somatic and otolith growth models using age as covariate, and differences in the allometric growth of SL and dry weight using otolith radius as covariate. Likewise, an ANCOVA was applied to test the differences in the individual growth rates using SL and age as covariates.

\section{Recruitment estimation}

Small pelagic fish resources are estimated from the yearly acoustic ECOMED survey carried out along the Spanish Mediterranean coasts in November-December on board the $R / V$ Cornide de Saave$d r a$. The period in which the survey is carried out is coincident with the anchovy recruitment season in the Mediterranean. The area covered in the acoustic tracking is subdivided into two strata: one extending from 30 to $100 \mathrm{~m}$ and the other from 100 to $200 \mathrm{~m}$. The acoustic survey encompasses four zones, among which Alborán Sea constitutes an independent one that extends from the Bay of 
Almería to the Strait of Gibraltar. This zone, which has a narrow shelf, has a grid of 39 transects, each one separated by 4 nautical miles. The acoustic tracking is done during daylight hours while fishing stations at night.

The estimations of abundance were obtained using an acoustic SIMRAD EK-500 unit at a frequency of $38 \mathrm{KHz}$ with a split-beam transducer. The elementary sampling distance unit was 1 nautical mile (Abad et al., 1998). For the identification of target species, pelagic trawls ( 9 and 10 trawls during ECOMED 2000 and 2001 respectively) were carried out with a net that had $20 \mathrm{~m}$ of vertical aperture equipped with a SIMRAD FR-500 net-sonder. The integration values of the target species related to each stratum were calculated according to the method proposed by MacLennan and Simmonds (1992). Only the catches from night trawls were used when the schools were dispersed. The target strength (TS) was: (20 log (L)-72.6) dB (Anonymous, 1986), where $\mathrm{L}$ is fish size.

The data provided in this study from the acoustic assessment originate from the ECOMED survey reports of an institutional nature, presented for fisheries management purposes. Data on the Bay of Málaga landings are from the IEO data base from the fisheries information network.

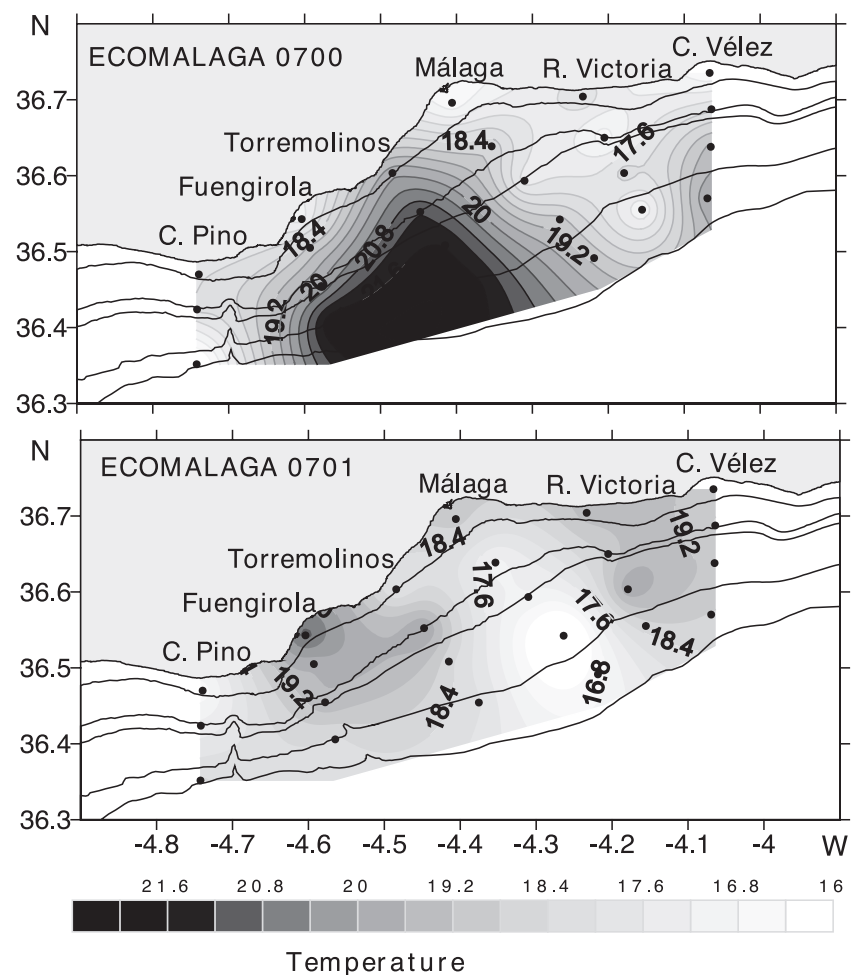

\section{RESULTS}

Since larval growth is mainly influenced by temperature and feeding (Buckley, 1984), it is deemed adequate to begin describing briefly the main differences observed between years with regard to the environmental characteristics that could have implications on growth at the early life stages. The anchovy larval cohorts sampled for daily growth in this study were sampled in July 2000 and July 2001, so only the environmental characteristics that conditioned their growth in this period are highlighted. However, due to the implications of spawning seasonality on recruitment, the anchovy egg and larval abundances over time are shown.

\section{Environmental features}

\section{Hydrographic conditions}

The hydrographic setting during the anchovy larval sampling for the daily growth study is shown in Figure 2, describing the respective surface $(10 \mathrm{~m})$ temperature and salinity distributions over the ECOMALAGA survey area in July 2000 and July 2001. The temperature regime of the water column at the $10 \mathrm{~m}$ and $20 \mathrm{~m}$ depth levels can be considered rep-

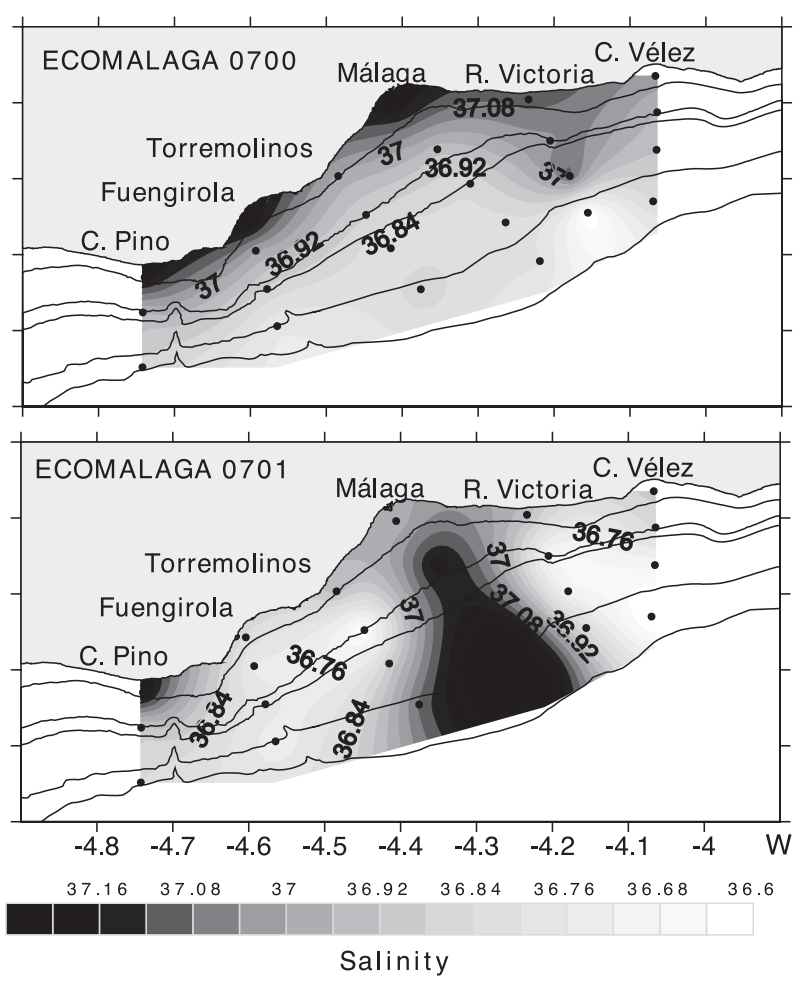

FIG. 2. - Surface temperature $\left({ }^{\circ} \mathrm{C}\right)$ and salinity distribution (PSU) of the ECOMALAGA survey in July 2000 and July 2001. 
resentative of the water column occupied by the anchovy larval stages (Palomera, 1991; Coombs et al., 1997).

During the July 2000 survey, the western sector of the sampled area showed higher temperatures in offshore waters. At the $10 \mathrm{~m}$ depth, the temperatures ranged from a minimum of $15.5^{\circ} \mathrm{C}$ to a maximum of $22.0^{\circ} \mathrm{C}$, while the temperature at $20 \mathrm{~m}$ varied from $14.3^{\circ} \mathrm{C}$ to $20.8^{\circ} \mathrm{C}$. During the July 2001 survey, the temperature at $10 \mathrm{~m}$ ranged from $15.0^{\circ} \mathrm{C}$ to $21.0^{\circ} \mathrm{C}$, while for the $20 \mathrm{~m}$ level these values ranged from $14.8^{\circ} \mathrm{C}$ to $19.9^{\circ} \mathrm{C}$. In the central part of the survey area, an intrusion of colder water masses was observed. The mean temperature at the $10 \mathrm{~m}$ level for 2000-2001 over the survey area was 18.7 and $18.4^{\circ} \mathrm{C}$ respectively, while for the $20 \mathrm{~m}$ level both years registered the same mean temperature of $16^{\circ} \mathrm{C}$. The same result was observed when only the stations surrounding the anchovy nursery grounds were considered, that is the two most coastal stations from transects $\mathrm{T}, \mathrm{M}$ and $\mathrm{R}$. No significant differences $(p>0.05)$ were observed between years $(18.5$ and $18.7^{\circ} \mathrm{C}$ for 2000 and 2001 respectively).

With respect to the salinity distribution (Fig. 2), the presence of Atlantic water masses, which is a normal characteristic of the Bay of Málaga coastal region, is evidenced. No values above the interface between Mediterranean and Atlantic water masses (37.5 PSU) were observed. The higher salinities and lower temperatures observed during July 2001 in the central part of the survey area indicate subsurface upwelling.

\section{Chlorophyll a}

The distribution of chlorophyll $a$ values over the survey area at 10 and $20 \mathrm{~m}$ in July 2000 and July 2001 is shown in Figure 3. Coincident with the subsurface upwelling located along the Malaga transect (M), a phytoplankton bloom was observed. However, no statistical differences $(\mathrm{p}>0.05)$ were observed in the individual or averaged values of chlorophyll $a$ over the depths 10 and $20 \mathrm{~m}$ between years. This bloom was particularly high at station M2, showing averaged values over the water column of $8 \mathrm{mg} / \mathrm{m}^{3}$.

\section{Mesozooplankton biomass}

Mesozooplankton biomass showed contrasting differences between the July 2000 and 2001 ECOMALAGA surveys (Fig. 4). These differences were statistically significant (ANOVA $\mathrm{p}<0.01$ ). The averaged values of zooplankton biomass during 2001 represent on the whole more than a two-fold
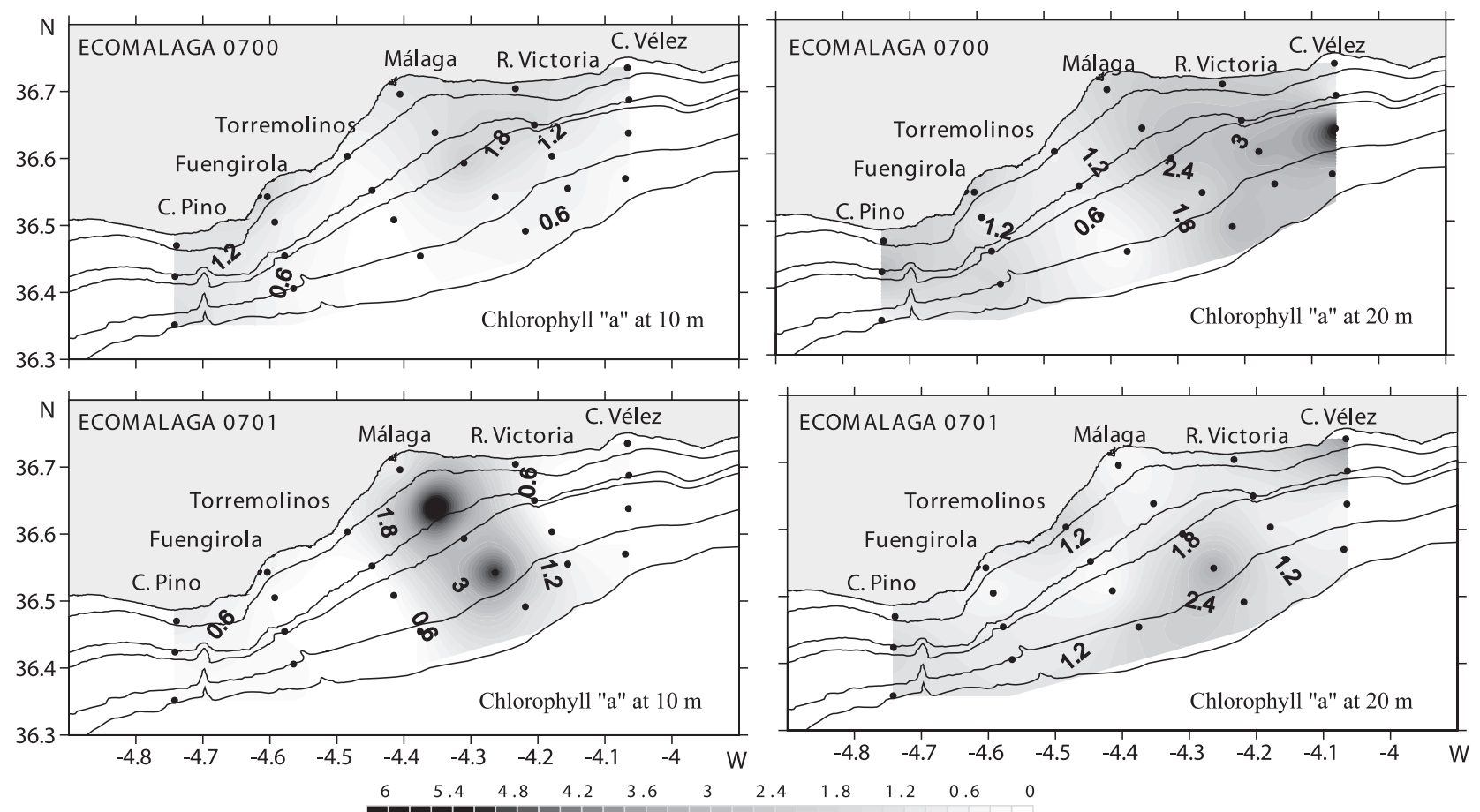

FIG. 3. - Chlorophyll $a\left(\mathrm{mg} / \mathrm{m}^{3}\right)$ distribution of the ECOMALAGA survey in July 2000 and July 2001 at the 10 and $20 \mathrm{~m}$ depths. 

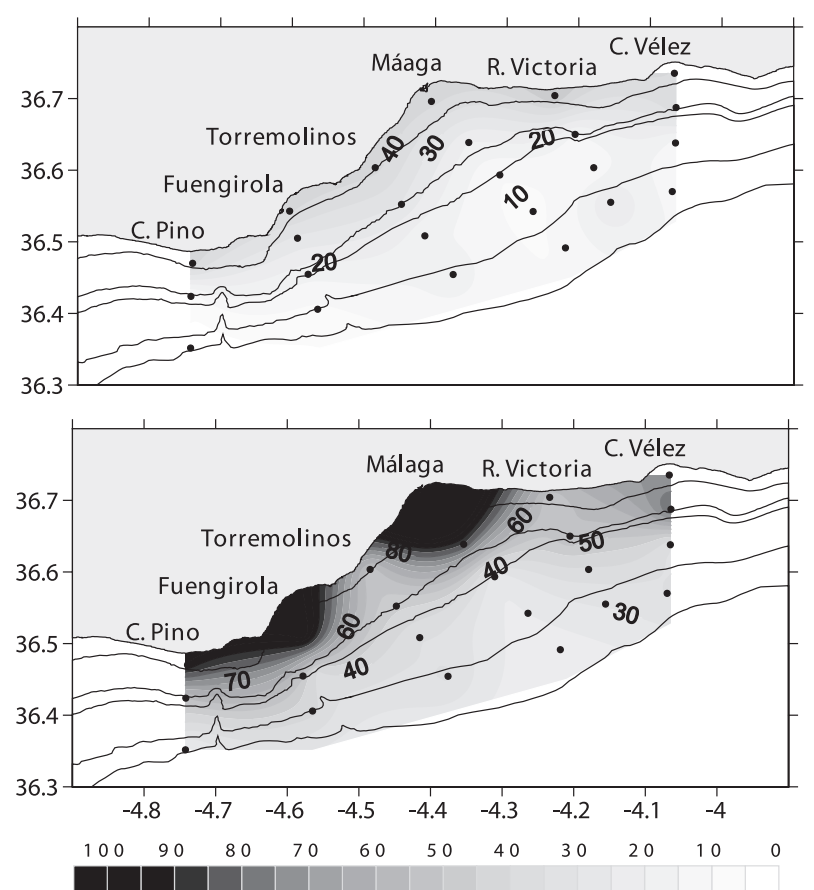

FIG. 4. - Mesozooplankton biomass $\left(\mathrm{mg} / \mathrm{m}^{3}\right)$ distribution of the ECOMALAGA survey in July 2000 and July 2001.

increase in comparison to the previous year (average values of 22.7 and $58.3 \mathrm{mg} / \mathrm{m}^{3}$ respectively).

The mesozooplankton distribution pattern shows a strong coastal gradient. As expected, coastal stations show higher values than the offshore stations, generally doubling the offshore values during both years.

\section{Anchovy larval growth}

A total of 1215 and 294 anchovy larvae were captured from 11 and 10 tows by the $1 \mathrm{~m}$ Bongo gear during the 2000 and 2001 anchovy spawning season (July) respectively. All the tows were carried

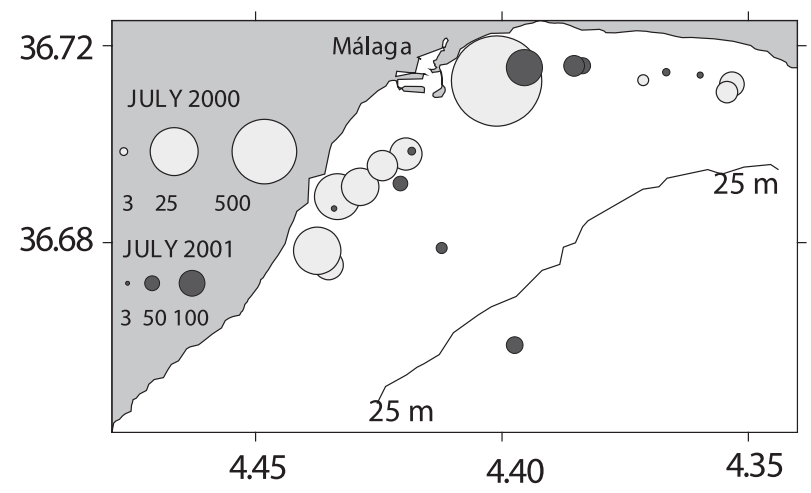

FIG. 5. - Larval catch and positions of the 10 minute surface hauls off the nursery grounds facing the city of Málaga carried out with the Bongo $1 \mathrm{~m}$ quadrangular opening are represented by proportional light-shaded (July 2000) and dark-shaded circles (July 2001).

out in the nursery grounds facing the eastern and western beaches of the city of Málaga (Fig. 5). Nevertheless, during both years, the highest catch rates occurred in the neighbouring waters off the port of Málaga.

A total of 193 and 188 anchovy larvae were randomly selected from each of the series of tows carried out during the 2000 and 2001 spawning season. Both larval populations were normally distributed over a mean size of 13.6 and $13.7 \mathrm{~mm}$ respectively (Table 1).

The somatic growth pattern for each anchovy larval population, expressed as somatic gain in body size (SL) or body mass (dry weight) with age follow power fits (Fig. 6). The results show that the larval population from the 2001 spawning season grows faster in length and in body mass than in the previous year. The ANCOVA test on the linear relationship of Ln SL and Ln Dry Weight versus Ln Age showed significant differences between years $(\mathrm{p}<0.01)$. However, this difference did not stand for otolith growth (Fig. 7).

TABLE 1. - Basic statistics of the principal parameters used in the daily growth analysis of the post-larval anchovy populations from July 2000 and 2001 (numbers in brackets correspond to standard deviation values).

\begin{tabular}{|c|c|c|c|c|}
\hline Survey & Variable & Mean (Std. Dev.) & Min (Max) & $\mathrm{N}$ \\
\hline July/00 & $\begin{array}{l}\text { Standard length }(\mathrm{mm}) \\
\text { Dry weight }(\mathrm{mg}) \\
\text { Nucleus } \\
\text { Otolith radius }(\mu \mathrm{m}) \\
\text { Days }\end{array}$ & $\begin{array}{c}13.62(2.28) \\
2.08(1.379) \\
4.7(0.38) \\
55.59(14.61) \\
20(4.42)\end{array}$ & $\begin{array}{c}8.86(21.33) \\
0.485(9.053) \\
4(6.4) \\
39.8(110.8) \\
11(34)\end{array}$ & 193 \\
\hline July/01 & $\begin{array}{l}\text { Standard length }(\mathrm{mm}) \\
\text { Dry weight }(\mathrm{mg}) \\
\text { Nucleus } \\
\text { Otolith radius }(\mu \mathrm{m}) \\
\text { Days }\end{array}$ & $\begin{array}{c}13.79(2.24) \\
1.77(1.33) \\
4.3(0.45) \\
42.61(11.64) \\
16(3.13)\end{array}$ & $\begin{array}{c}7.62(19.69) \\
0.182(9.75) \\
3.4(5.9) \\
15.2(86.8) \\
8(27)\end{array}$ & 188 \\
\hline
\end{tabular}



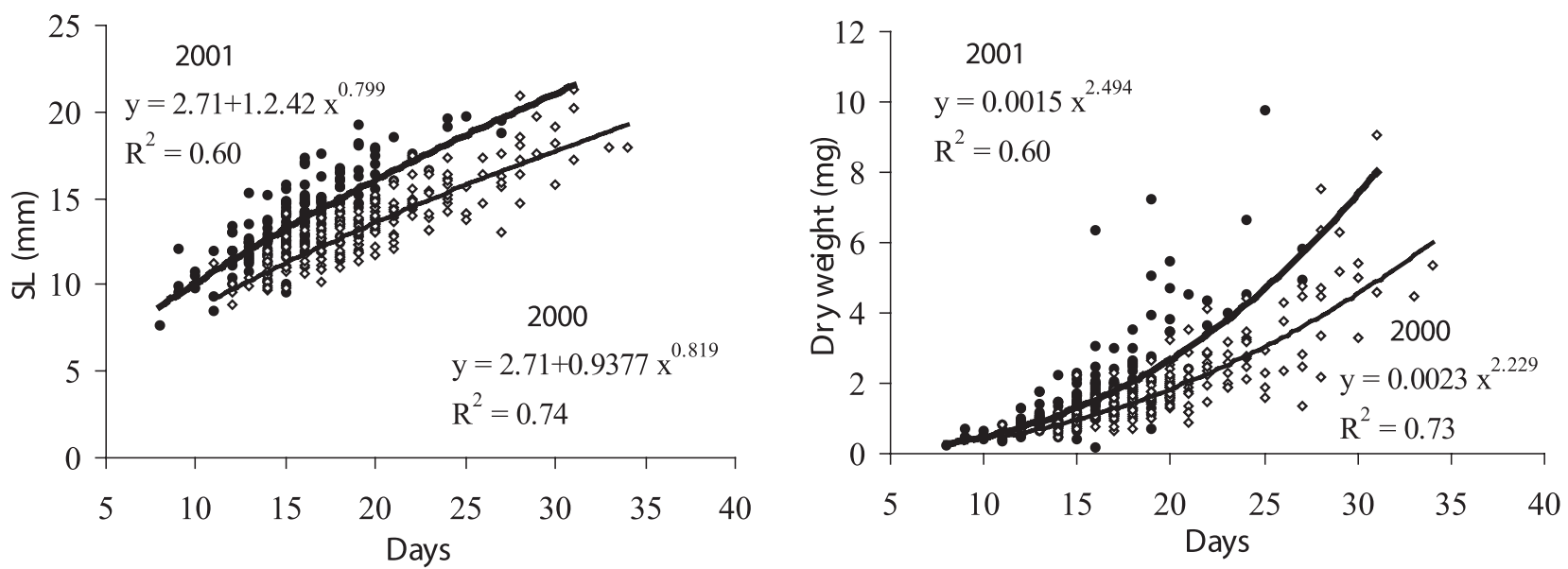

FIG. 6. - Somatic growth models of larval size (SL) and dry weight from the anchovy larval populations spawned during July 2000 and 2001.

The estimated growth rates for the larvae sampled during 2001 were $20 \%$ higher than those of larvae sampled in 2000. The estimated growth rate for a $10 \mathrm{~mm}$ larva during the 2000 spawning season was $0.49 \mathrm{~mm} /$ day, while this value increased to 0.62 $\mathrm{mm}$ /day for the 2001 population. At the $15 \mathrm{~mm}$ size class, the estimated daily growth rates of the 2000 and 2001 populations were 0.43 and $0.54 \mathrm{~mm} /$ day respectively. At the $20 \mathrm{~mm}$ size class, these values were 0.40 and $0.50 \mathrm{~mm} /$ day respectively. Throughout the size classes, there was an average difference of $0.1 \mathrm{~mm} /$ day in favour of the 2001 population. This means a temporal difference of a week to reach a $20 \mathrm{~mm}$ size.

The differences observed in the daily growth rates are clearly shown in Figure 8, which represents the individual estimates of growth rates of the respective populations. An ANCOVA test was applied to test whether these differences were significant, using age as covariate and likewise with size. Both tests showed significant differences $(\mathrm{p}<0.01)$. However, the estimates of otolith growth

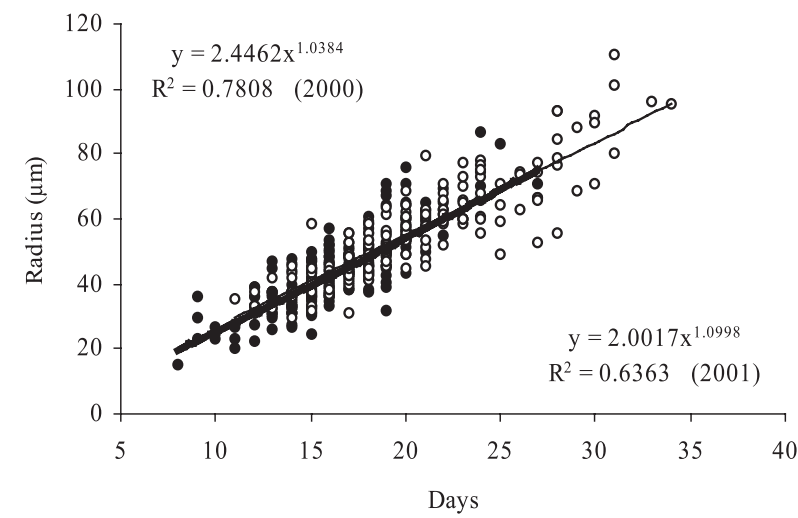

FIG. 7. - Otolith growth model for larval E. encrasicolus population spawned during July 2000 and July 2001. rates do not show these differences which is caused by the relationship of otolith radius and increments (Fig. 7), meaning that for a similar otolith radius size, similar ages are attributed. In general, slowergrowing larvae have larger otoliths than fast-growing larvae in the same size class.

The relative growth of a body constituent such as SL or dry weight to another body element such as the otolith radius also provides an insight into the differences observed. The allometric relationship between SL and dry weight with otolith radius show higher larval sizes and weights per otolith radius

TABLE 2. - Allometric growth models of SL and dry weight relationship on otolith radius of the anchovy populations from the 2000 and 2001 spawning seasons.

Independent variable: Otolith radius

Survey Dependent variable Relative growth equation $\mathrm{R}^{2} \quad \mathrm{~N}$

\begin{tabular}{lllll}
\hline $07 / 00$ & SL (mm) & $y=1.2314 * x^{0.5996}$ & 0.86 & 193 \\
& Dry weight (mg) & $y=0.0005 \times x^{2.0486}$ & 0.85 & \\
$07 / 01$ & SL (mm) & $y=1.6829 * x^{0.5625}$ & 0.85 & 188 \\
& Dry weight (mg) & $y=0.0005 * x^{2.1501}$ & 0.85 & \\
\hline
\end{tabular}

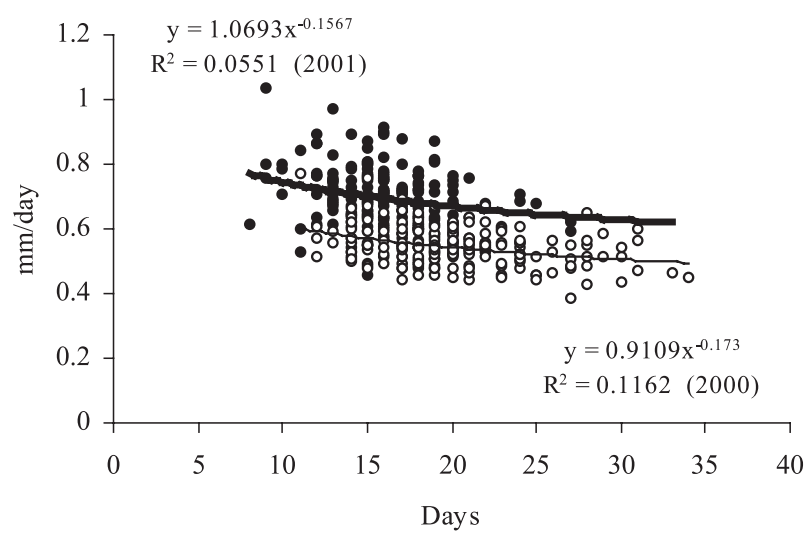

FIG. 8. - Individual growth rates of the E. encrasicolus larval populations spawned during July 2000 and 2001. 

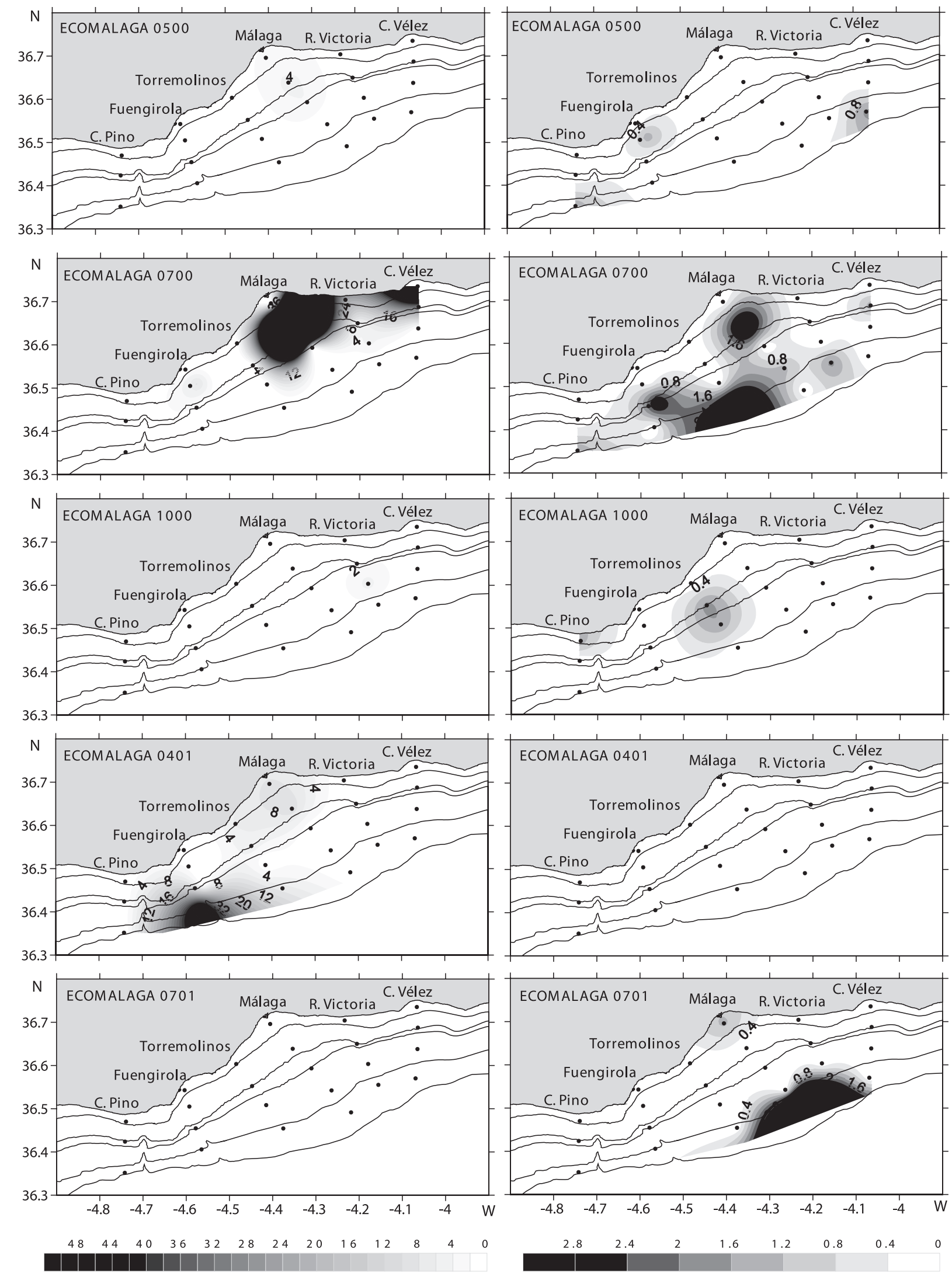

$\mathrm{Eggs} / \mathrm{m}^{2}$

Larvae/m 2

FIG. 9. Anchovy (E. encrasicolus) egg and larval distributions off the Bay of Málaga from the ECOMALAGA surveys series during years 2000 and 2001 


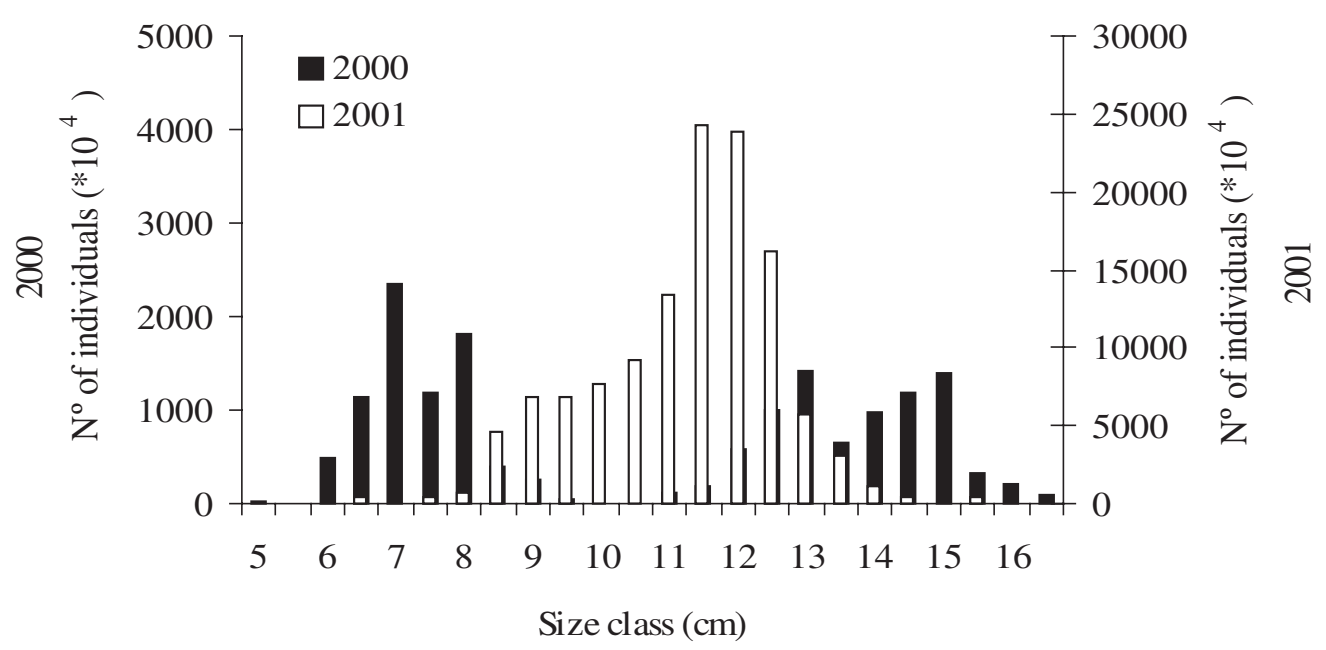

FIG. 10. - Acoustic estimates of E. encrasicolus individuals by size classes from the 2000 and 2001 ECOMED surveys.

unit in the 2001 population (Table 2). ANCOVA tests using Ln SL and Ln Dry weight using Ln Otolith radius showed significant differences $(\mathrm{p}<0.01)$.

\section{0-2001 anchovy spawning seasonality}

From the quarterly monitoring surveys carried out during 2000 and 2001, anchovy spawning was observed from spring to autumn (Fig. 9). The highest egg and larval abundances among all the ECOMALAGA surveys occurred in July 2000, while the lowest egg and larval abundances occurred during spring and autumn of that year. During 2001, early anchovy spawning is observed from the results of the April survey, which was not accompanied by the presence of larvae. In contrast to the preceding year, the summer survey of July 2001 showed insignificant egg abundances at two stations. Likewise, only two stations presented anchovy larvae in this survey.

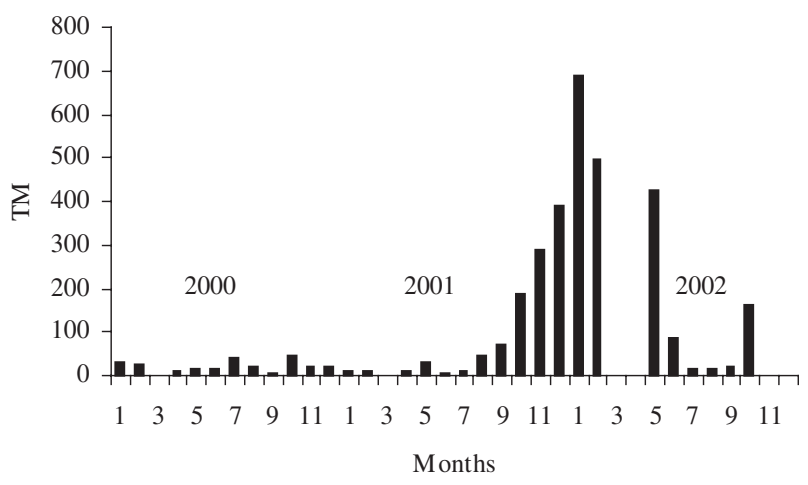

FIG. 11. - Anchovy landings by months during years 2000, 2001 and 2002 (March and April 2002 was a biological stop for the fishing fleet).
The area, perimeter, major and minor axis of 68 and 62 anchovy eggs produced during the respective peak spawnings of 2000 (summer) and 2001 (spring) were measured by an image analysis system. A one factor ANOVA presented significantly greater egg area, perimeter and major axis of the eggs spawned during $2001(\mathrm{p}<0.01)$.

\section{Anchovy recruitment}

The results of the acoustic estimates (in number of individuals by size class) for the Alborán Sea anchovy are shown in Figure 10. The anchovy stock estimates were 13,000 tons for the year 2001 (Giráldez, 2002). For the year 2000, a lack of ship time hampered the coverage of the westernmost sector of the Alborán Sea. Nevertheless, 1716 tons were estimated by Giráldez and Alemany, (2002b) for the NE Alborán zone (from Cape Gata to Fuengirola). The size frequency distributions of the acoustic estimates differ greatly. Whereas during 2000 a bi-modal distribution of sizes was observed, in which the juveniles (sizes from 6 to $9 \mathrm{~cm}$ ) are completely segregated from the adult stock, in 2001 the distribution is unimodal, with a slight negative skew in which the recruit size classes showed a significant increase. Whereas during the 2000 recruitment season the anchovy recruits were distributed over the $7 \mathrm{~cm}$ size class, in the 2001 recruitment season the recruitment size increased towards the $9 \mathrm{~cm}$ size class (Fig. 10).

This increase in the anchovy stock during the 2001 recruitment was substantiated in the landings of anchovy recorded in the port of Málaga (Fig. 11). Landings showed an increasing trend at the start of the recruitment season, from September onwards. 


\section{DISCUSSION}

There is growing evidence from field-based research that enhanced growth rates in the larval stages play an important role in the survival rate of the early life stages of a wide range of species (Hovenkamp, 1992; West and Larkin, 1987; Post and Prankevicius, 1987; Wilson and Meekan, 2002; Rilling and Houde, 1999), showing their influence on recruitment success in a number of species (Campana, 1996; Bergenius et al., 2002). It is reasonable to expect a relationship between larval growth and recruitment because studies on other anchovy species have shown that survival within each ontogenic larval stage is size-specific and growth-dependent (Rilling and Houde, 1999), that mortality declines with age, and that one of its main causes is predation (Leak and Houde, 1987; Folkvord and Hunter, 1986). It is believed that the results of this study will shed some new evidence on the influence of upgraded anchovy larval growth on recruitment success.

It is also significant to highlight the role of Bay of Málaga as a nursery ground that formerly commercially fished the larval shoals, similar to the actual Japanese "shirasu" fishery, which is currently researched for conservation and assessment of small pelagic resources (Maki and Kishida, 1997).

For Agostini and Bakun (2002), the Bay of Málaga represents an example of an eastern ocean anchovy-spawning habitat, a sheltered bight downstream from an upwelling centre located on the western Alborán coast. During July 2001, a subsurface upwelling was detected in the central part of the survey area (see Fig. 2). This hydrographic feature is produced by the effect of cyclonic gyres released from the Atlantic mainstream (Cano and Gil, 1984; Vargas et al., in press). As a result, higher primary production in the surface layers is induced, as demonstrated by the extreme chlorophyll $a$ values in the Malaga transect (see Fig. 3). This swell of higher primary production may have caused the two-fold increase of mesozooplankton biomass (Fig. 4). The mesozooplankton biomass increase was especially noteworthy in the coastal region, hence affecting the nursery grounds that constitute a narrow strip of shallow inshore turbid and mixed waters, where larval shoals concentrate. Their concentration mainly at night facilitates their sampling, as many as $\mathbf{5 0 0}$ larvae being obtained in a single tow (see Fig. 5).

The estimation of age by otolith microstructure requires a consistent degree of precision that in the long term benefits the reliability of growth rate estimates. Precision is gained with the age of larvae over 10 days old (Moksness et al., 2000) by showing sharper and clearer edges of increments, thus also allowing more accurate increment measurements. Most of the larval stages analysed fall under this category, since the mean age for the 2000 population was 20 days, and that of the 2001 population was 16 days (Table 1 ).

The SL and dry weight at age relationships (Fig. 6) showed a higher growth pattern of the anchovy larval cohort sampled during the 2001 spawning season. Contrarily, this was not so for the relationship of otolith radius at age, in which for an equal size of otolith radius a similar age was ascribed. The allometric relationship of somatic growth expressed in SL and dry weight in relation to otolith radius showed greater larval size in length and in weight per otolith unit measurement in the 2001 larval population. Generally, for a given larval size, a slowgrowing larva has a larger otolith size than a fastgrowing one. This is due to the greater time span to deposit increments in a slow-growing larva than a fast-growing one, unless great differences occur in the widths of increments. Increment width is highly influenced by temperature (Pavlov et al., 2000; Karakiri et al., 1989), and in our case, the temperature regime between years was similar, thereby not showing significant differences in the sampled area.

The variability of growth rates at the early stages can provide another perspective to the problem of fluctuating recruitment levels (Houde, 1987). As a result of the differential daily growth observed during the 2000 and 2001 spawning seasons, the estimated daily growth rates showed an increase of $20 \%$ in terms of SL increment during the latter spawning season. Houde (1987) indicated that small variations in the growth rates could lead to major recruitment oscillations, and in the present case the variation of the daily growth rate observed between 2000 and 2001 cannot be considered small. From the ontogenic stage duration viewpoint, there would be a time span difference of 17 days in favour of the 2001 population to attain a size of $40 \mathrm{~mm}$, which corresponds to the metamorphic stage of squamation (D'Ancona, 1931) from the larval to the juvenile stage, assuming that each of the anchovy larval populations had followed their respective daily growth model to the metamorphic size. This difference increases to 32 days to reach the size of a $7 \mathrm{~cm}$ juvenile anchovy. Since mortality is stage-duration and size specific (Rilling and Houde, 1999), this time- 
span difference has immense consequences on survival rates.

The size frequency distributions of the recruitment acoustic surveys provided by the pelagic trawls (see Fig. 10) seem to respond to the different growth patterns observed during the 2000 and 2001 spawning seasons. Since the Mediterranean anchovy's size at first maturity is $10.9 \mathrm{~cm}$ (Giráldez and Abad, 1995), below this threshold size can be considered as -0 age class. During the 2000 spawning season, most recruits were in the modal size class of $7 \mathrm{~cm}$, which would correspond to an estimated birthdate distribution of mid-June calculated from the date of capture by the pelagic trawls (mid-December), while for the 2001 population this size class would have been born by mid-July. These estimates are based on the assumption that the respective larval daily growth patterns for each year are followed throughout their developmental stages. This spawning seasonality is in agreement with the observations of Rodríguez, (1990) and Rodríguez and Rubín (1986). The fact that practically no recruits of $7 \mathrm{~cm}$ appeared in the size distribution of the 2001 pelagic trawls is consistent with the egg survey carried out during July 2001, which showed negligible egg catches in the samples (Fig. 9). On the other hand, the modal size class of recruits during the 2001 recruitment season was $9 \mathrm{~cm}$ (Fig. 10). From the estimates of the daily growth model, this size class would have been born by the beginning of May, which agrees with the early spring spawning observed during that year and the much lower larval catch rates observed in July in the nursery grounds (Fig. 5). However, such differences in the recruit size classes could also be attributed to daily growth differences, as observed by Waldron (1995) in the South African anchovy (Engraulis capensis). A difference of $0.1 \mathrm{~mm} /$ day between years of high and low daily juvenile growth rates, similar to our estimates, could cause interannual variations of $2 \mathrm{~cm}$ in the recruit size classes.

Bearing in mind that the sampled anchovy larvae belonged to by far the most important nursery grounds of this species in the region (García et al., 1981), and that the anchovy landings in the port of Málaga represent on average $85 \%$ of the total amount landed in the SW Mediterranean region, i.e. the Alborán Sea (Giráldez and Alemany, 2002a) (see Fig. 11), it is reasonable to draw a direct relationship from the higher growth rates observed in late larval stages and the successful recruitment for the 2001 year class.
The causes of the substantial increase in daily growth rates in the late larval stages of anchovy during the 2001 spawning season seem to be related to an enhanced production in the Bay of Málaga, possibly induced by the subsurface upwelling detected in the central part of the ECOMALAGA survey area, evidenced by the high values of chlorophyll $a$ in this area. This may have caused the higher production at the higher trophic level as observed by the two-fold increase in the mesozooplankton biomass values during July 2001. Higher productivity induced by hydrographic phenomena, such as upwelling or river outflows, has been related to anchovy recruitment success in other regions (Borja et al., 1998; Cury et al., 1996).

Considering that the Mediterranean anchovy larvae feed mainly on the developmental stages of copepods, mainly nauplii (Tudela and Palomera, 1995; Conway et al., 1998), and that the predominant groups of zooplankton in the Bay of Málaga are composed of copepods and cladocers (Pérez-Martin and Camiñas, 1995), whose relative proportion is $60 / 20$ in favour of the former (Rodríguez, 1983), a great increase in zooplankton production could have led to a greater availability of feeding resources. Rilling and Houde (1999) observed in the Bay anchovy (Anchoa mitchilli) a positive relationship of larval growth rate with temperature and zooplankton abundance as a proxy for prey abundance.

Nonetheless, the maternal effects on growth cannot be overlooked. Monteleone and Houde (1990) studied the influence of maternal size of striped bass (Morone saxatilis) on the growth of larvae, finding that smaller maternal sizes produced smaller offspring that rendered lower growth rates. Maternal effects can also be due to parental genetic qualities, as observed in herring (Høie et al., 1999). The measurement of egg dimensions was thought adequate to assess quality traits of the parental population and enhanced larval characteristics that may favour survival, as documented extensively in the literature for a number of species (Marteinsdottir and Steinarsson, 1998; Gamble et al., 1985; Moodie et al., 1989; Duarte and Alcaraz, 1989). The area, perimeter, major and minor axis of 68 and 62 anchovy eggs showed significantly greater egg area, perimeter and major axis of the eggs spawned during 2001 $(p<0.01)$. Hence, the higher growth rates of the 2001 offspring could also be attributed to the parental quality of their spawners.

Regardless of which factors may have caused higher growth rates in the 2001 anchovy larvae, 
either parental quality or the more than suitable production-related environmental conditions prevailing during their development, or a combination of both, this study provides evidence on the influence of growth rates estimated from field captured anchovy larvae on recruitment.

\section{ACKNOWLEDGEMENTS}

The authors express their gratitude to the crew of $R / V$ Odón de Buen for their patience in working throughout some long night hours without ever showing the slightest complaint.

\section{REFERENCES}

Abad, R. and A. Giráldez. - 1990. Concentrations de Capros aper dans la Mer d`Alboran (Méditerranée Espagnole). Rapp. Comm. int. Mer. Médit., 32, 1: 256.

Abad, R., J. Miquel, M. Iglesias and F. Álvarez. - 1998. Acoustic estimation of abundance and distribution of anchovy in the NW Mediterranean. Sci. Mar., 62(1-2): 37-43.

Agostini, V. and A. Bakun. - 2002. "Ocean triads" in the Mediterranean Sea: physical mechanisms potentially structuring reproductive habitat suitability (with application to European anchovy, Engraulis encrasicolus). Fish. Oceanogr., 11(3): 129142.

Andersen, T. and E. Moksness. - 1988. Manual for reading daily increments by the use of a computer program. Flodevigen Meldingen 4. Directorate of Fisheries. Flodevigen Biological Station. Arendal.

Anonymous. - 1986. Report of the Herring Assessment Working Group for the area south of $62^{\circ}$ N. ICES CM 1986/ Assess: 19.

Anonymous. - 1993. Report of the Clupeoids Otolith Microstructure Workshop. Inf. Téc. del Inst. Esp. Oceanogr., 145.

Bailey, K.M. and E.D. Houde. - 1989. Predation on eggs and larvae of marine fishes and the recruitment problem. Adv. Mar. Biol., 25: $1-83$.

Bergenius, M.I. Meekan, R. Robertson and M.I. McCormick. 2002. Larval growth predicts the recruitment success of a coral reef fish. Oecologia, 131(4): 521-525.

Borja, A., A. Uriarte, J. Egana, L. Motos, V. Valencia. - 1998. Relationships between anchovy (Engraulis encrasicolus) recruitment and environment in the Bay of Biscay (1967-1996). Fish. Oceanogr., 7(3-4): 375-380.

Buckley, L.J. - 1984. RNA-DNA ratio: an index of larval fish growth in the sea. Mar. Biol. 80, 291-298.

Camiñas, J.A., N. Cano, D. Cortes, V. Diaz Del Rio, A. García and J.P. Rubin. - 1996. "Ecomalaga": An ecosystem analysis of the SW Spanish Mediterranean coasts. In: E. Özhon (ed.), $M E D-$ COAST 95, (1): 1-13.

Campana S.E. and J.D. Neilson. - 1982. Daily growth increments in otoliths of starry flounder (Platichthys stellatus) and the influence of some environmental variable in their production. Can. J. Fish. Aquat. Sci., 39: 937-942.

Campana S.E. and J.D. Neilson. - 1985. Microstructure of fish otolith. Can. J. Fish. Aquat. Sci., 42: 1014-1032.

Campana, S. E. -1996. Year-class strength and growth rate in young Atlantic cod Gadus morhua. Mar. Ecol. Prog. Ser., 135(1-3): 21-26.

Campana, S.E. and C. Jones. - 1992. Analysis of otolith microstructure data. In: D.K. Stevenson and S. E. Campana (eds.), Otolith Microstructure Examination and Analysis. Can. Spec. Publ. Fish. Aquat. Sci., 117: 73-100.

Cano, N. and J. Gil. - 1984. Campaña Hidrológica Alboran 78. Bol. Inst. Esp. Oceanog., 1(2): 114-125.

Conway, D.V.P., S.H. Coombs and C. Smith. - 1998. Feeding of anchovy Engraulis encrasicolus larvae in the northwestern Adriatic Sea in response to changing hydrobiological conditions. Mar. Ecol. Prog. Ser., 175: 35-49.

Coombs, S., O. Giovanardi, D. Conway, L. Manzueto, N. Halliday and C. Barrett. - 1997. The distribution of eggs and larvae of anchovy (Engraulis encrasicolus) in relation to hydrography and food availability in the outflow of the river Po. Acta. Adriat. 38(1): 33-47.

Cury, P., C. Roy and Faure, V. - 1998. Environmental constraints and pelagic fisheries in upwelling areas: the Peruvian puzzle. $S$. Afr. J. mar. Sci., 19: 159-167.

D’Ancona, U. - 1931. Uova e larve stadi giovanili di Teleostei. Ordine: Malacopterygii. Famiglia: Clupeidae. Fauna e Flora Golfo Napoli. Monografia, 38: 1-16.

Duarte, C.M. and M. Alcaraz. - 1989. To produce many small or few large eggs: A size-independent reproductive tactic of fish. Oecologia, 80(3): 401-404.

Dulčic, J. - 1997. Growth of anchovy, Engraulis encrasicolus (L.), larvae in the Northern Adriatic Sea. Fish. Res., 31, 189-195.

Folkvord, A. and J.R. Hunter. - 1986. Size specific vulnerability of northern anchovy (Engraulis mordax) larvae to predation by fishes. Fish. Bull. US, 84: 859-869

Gamble, J.C., P. MacLachlan and D.D. Seaton. - 1985. Comparative growth and development of autumn and spring spawned Atlantic herring larvae reared in large enclosed ecosystems. Mar. Ecol. Prog. Ser., 26(1-2): 19-33.

García, A., D. Cortés and T. Ramírez. - 1998. Daily larval growth and RNA and DNA content of the NW Mediterranean anchovy Engraulis encrasicolus and their relations to the environment. Mar. Ecol. Progr. Ser., 166, 237-245.

García, A., J. Crespo and J.D. Rey. - 1981. A contribution to the knowledge of the southern part of Spain's Mediterranean coastal zone including a description of a beach seine fishery. FAO. CGPM, Etudes et Revues, 58: 139-155.

Geffen, A.J. - 1982. Otolith ring deposition in relation to growth rate in herring (Clupea harengus) and turbot (Scophthalmus maximus) larvae. Mar. Biol., 71: 317-326

Giráldez, A. and F. Alemany. - 2002a. The small pelagic fisheries in the South-Mediterranean Region (Western Mediterranean Sea): Past and present state. GGFCM-SAC. Sub-Committee of Stock Assessment. Working Group on small pelagic species Rome, Italy, 20-22 March, 2002.

Giráldez, A. and F. Alemany. - 2002b. Management unit: Northern Alborán Sea, Engraulis encrasicolus. GFCM-SAC. Sub-Committee of Stock Assessment. Working Group on small pelagic species Rome, Italy, 20-22 March, 2002.

Giráldez, A. - 2002. Campaña ECOMED 2001. Informe Interno Inst. Esp. Oceanogr.

Giráldez, A. and R. Abad. - 1991. La pesquería de cerco en la Región Surmediterránea en 1989-1990. Inf. Téc. Inst. Esp. Oceanogr., 105: 1-31.

Giráldez, A. and R. Abad. - 1995. Aspects on the reproductive biology of the Western Mediterranean anchovy from the coasts of Málaga (Alboran Sea). Sci. Mar., 59: 15-23.

Giráldez, A. and R. Abad. - 2000. Serie histórica de capturas de los pequeños pelágicos en el Mediterráneo español (1945-1997) y capturas, esfuerzos y flota de cerco de la Región Surmediterránea. Datos y Resúmenes 13: $26 \mathrm{pp}$.

Høie, H., A. Folkvord and A. Johannessen. - 1999. The influence of different parental combinations and incubation temperature on the RNA and DNA content of herring larvae at hatching: a pilot study. J. Fish Biol., 55(A): 110-118.

Houde, E.D. - 1987. Fish early life dynamics and recruitment variability. Am. Fish. Soc. Symp., 2: 17-29.

Hovenkamp, F. - 1992. Growth-dependent mortality of larval plaice Pleuronectes platessa in the North Sea. Mar. Ecol. Progr. Ser., 82: 95-101.

Karakiri, M. and H. Westernhagen. - 1989. Daily growth patterns in otoliths of larval and juvenile plaice (Pleuronectes platessa L.): Influence of temperature, salinity, and light conditions. In: The early life history of fish. The Third ICES Symposium, Bergen, 3-5. Rapp. P. -V. Reun. CIEM., (191): 376-382.

Leak J.C. and E.D. Houde. - 1987. Cohort growth and survival of bay anchovy Anchoa michilli larvae in Biscayne Bay, Florida. Mar. Ecol. Prog. Ser., 37: 109-122

Legget, W.C. and E. DeBlois. - 1994. Recruitment in marine fishes: Is it regulated by starvation and predation in the egg and larval stages? Neth. J. Sea Res., 32: 119-134. 
MacLennan, D. and E. Simmonds. - 1992. Fisheries acoustic. Edited by Chapman and Hall. London.

Maki, S. and T. Kishida. - 1997. The yearly fluctuation of survival indices before and after shirasu, the larval stage, of Japanese sardine from 1979 to 1992 off the Pacific coast of Japan. Fish. Sci., 63(1): 60-63.

Marteinsdottir, G. and A. Steinarsson. - 1998. Maternal influence on the size and viability of Iceland cod Gadus morhua eggs and larvae. J. Fish Biol., 52(6): 1241-1258.

Moksness E. and P Fossum. - 1991. Distinguishing spring- and autumn spawned herring larvae (Clupea harengus L.) by otolith microstructure. ICES J. Mar. Sci., 48: 61-66.

Moksness E., M. Belchier, C. Clemmesen, D. Cortés, A. Doan, A. Folkvord, A. García, A.J. Geffen, H. Høie, A. Johannessen, H. Pontual, T. Ramírez, D. Schnack and B. Sveinsbø. - 2000. Precision and Accuracy of Tools in Recruitment Studies (PARS) (Final Report UE FAIR CT 96-1371)(1997-1999).

Monteleone, D.M. and E.D. Houde. - 1990. Influence of maternal size on survival and growth of striped bass Morone saxatilis Walbaum eggs and larvae. J. Exp. Mar. Biol. Ecol., 140(1-2): 1-11.

Moodie, G.E.E., N.L. Loadman, M.D. Wiegand and J.A. Mathias. 1989. Influence of egg characteristics on survival, growth and feeding in larval walleye (Stizostedion vitreum ). Can. J. Fish. Aquat. Sci., 46(3): 516-521.

Palomera I. - 1991. Vertical distribution of eggs and larvae of Engraulis encrasicolus, in stratified waters of the Western Mediterranean. Mar. Biol., 111: 37-44.

Pavlov, D.A., E. Moksness and V.A. Burmenski. - 2000. Otolith microstructure characteristics in White Sea spring-spawning herring (Clupea pallasi marisalbi Berg) larvae. ICES J. Mar. Sci., (57)4: 1069-1076.

Pérez-Martín M. and J.A. Camiñas. - 1995. Variación estacional del mesozooplancton de la plataforma continental del Mar de Alborán. In: Primer Congreso Ibérico del Plancton. Univ. de Coimbra. Libro de resumenes.

Peterman, R.M., M. J. Bradford, N.C.H. Lo, and R. D. Methot. 1988. Contribution of early life stages to interannual variability in recruitment of northern anchovy (Engraulis mordax). Can. J. Fish. Aquat. Sci., 45: 8-16.
Post, J.R. and A.B. Prankevicius. - 1987. Size-selective mortality in the young-of-the-year yellow perch (Perca flavescens): evidence from otolith microstructure. Can. J. Fish. Aquat. Sci., 44: 1840-1847.

Reina-Hervás, J.A. and P. Serrano. - 1987. Structural and seasonal variations of inshore fish populations in Málaga Bay, Southeastern spain. Mar. Biol., 95: 501-508.

Rilling, G.C. and E.D. Houde. - 1999. Regional and temporal variability in growth and mortality of bay anchovy, Anchoa mitchilli, larvae in Chesapeake Bay. Fish. Bull., 97(3): 555-5679.

Rodríguez, J. - 1983. Estudio de la comunidad planctónica nerítica en el mar de Alborán. Ciclo del zooplancton. Bol. Inst. Esp. Oceanogr., 1(1): 19-44.

Rodríguez, J.M. and J.P. Rubín. - 1986. The sardine and anchovy ichthyoplankton captured in nine fixed stations located at the Bay of Málaga from May to December of 1977. Rapp. Comm. Int. Mer Medit., 30, 2.

Rodríguez, J.M.. - 1990. Contribución al conocimiento del ictioplancton del mar de Alborán. Bol. Inst. Esp. Oceanogr., 6: 1-20.

Tudela, S., and I . Palomera. - 1995. Diel feeding intensity and daily ration in the anchovy Engraulis encrasicolus in the Northwest Mediterranean Sea during the spawning period. Mar. Ecol. Prog. Ser., 129(1-3): 55-61.

Vargas, M., A. Chasles, A. Berthelemot, T. Rámirez, D. Cortés, A. García, A. Carpena, J.M. Serna, M. Sebastián, J. Cortés and J.P. Alvarez. - (in press). Proyecto ECOMALAGA 1992-2001. Parte I: Oceanografía Física. Inf. Téc. Inst. Esp. Oceanogr.

Waldron, M.E - 1995. Evidence of reduced growth rates of anchovy recruits off South Africa in 1989 and 1991. S. Afr. J. mar. Sci., 15: 263-267.

West, C.J. and P.A. Larkin. - 1987. Evidence for size-selective mortality of juvenile sockeye salmon (Oncorhynchus nerka) in Babine Lake, British Columbia. Can. J. Fish. Aquat. Sci., 44(4): 712-721.

Wilson, D.T. and M.G. Meekan. - 2002. Growth-related advantages for survival to the point of replenishment in the coral reef fish Stegastes partitus (Pomacentridae). Can. J. Fish. Aquat. Sci., 53: $1246-1253$

Scient. ed.: P. Olivar 